\title{
The Local Wisdom of Angkola in Efforts to Love the Environment
}

\author{
Yusni Khairul Amri ${ }^{1}$, Diani Syahputri ${ }^{2}$ \\ ${ }^{1,2}$ Universitas Muhammadiyah Sumatera Utara, Medan, Indonesia \\ amri_lubis@ymail.com
}

Keywords

angkda indigenous wisdom love the environment; anthropdinguistics

\section{Introduction}

The universe and the environment that have given signs of severe damage are marked by the warning "Earth Day" on April 22 has a function to increase human awareness of the earth. Likewise the "World Forest Day" celebrated on March 21 serves to remember the importance of forests, and the "Environment Day" is celebrated every June 5 to function to utilize natural resources on earth.

Forests are increasingly shrinking, the environment continues to experience exploitation of its contents so that environmental damage occurs everywhere in the Indonesian Archipelago. The universe that began Indonesian Forest Damage 1.47 Million Hectares per Year. Damage to tropical forests in 2018 alone reached 120 thousand square kilometers or the equivalent of 30 soccer fields. "In 2019, Forest Watch Indonesia: 1.47 Million Hectares of Forest Are Lost Every Year," said Akmal (Pikiran-rakyat.com)

Everard (2020: 7) the complex relationship between society and the environment by maintaining a fully functioning and fully functioning ecosystem and its associated environmental and health benefits is key to preventing the emergence of new pandemics. The loss of these benefits through ecosystem degradation, such as deforestation,

This is in accordance with the opinion of Adisaputra (2010: 57) that, changing ecological conditions, a number of entities will experience changes, efforts to love the environment and even disappear altogether. As a result, a number of lexical recorded through the conceptualization process in the mind of the speaker becomes functional lexical for use. That means that the extinction of locallanguages means that all cultural values stored in that language are buried, including various wisdom in that culture. 
Every part of the ecosystem is related to the Language lexicon, so the lexicon disappears. Language also disappears as the lexicon conception. A lexicon or an expression that mentions a situation or for naming something caused by a need, a situation in the environment using language as a sign language system is a system of codes used by social groups based on conventions between conventional members of the community for the community.

Likewise, speakers of customs and traditions use lexicons that exist in the forest, natural and animal environments in various traditional ceremonies. Halliday (1978) mentions language as a social semiotic. Social semiotic according to Sinar (2003) is a system of meaning that is realized through a linguistic system, which is manifested in the use of the lexicon in traditional ceremonies in the form of oral traditions.

Every part of the ecosystem is related to the Language lexicon, so the lexicon disappears. Language also disappears as the lexicon conception. A lexicon or an expression that mentions a situation or for naming something caused by a need, a situation in the environment using language as a sign language system is a system of codes used by social groups based on conventions between conventional members of the community for the community.

Likewise, speakers of customs and traditions use lexicons that exist in the forest, natural and animal environments in various traditional ceremonies. Halliday (1978) mentions language as a social semiotic. Social semiotic according to Sinar (2003) is a system of meaning that is realized through a linguistic system, which is manifested in the use of the lexicon in traditional ceremonies in the form of oral traditions.

\section{Review of Literatures}

Environmental degradation was raised to be a linguistic concern, which implies a different approach that bridges language studies with the environment into a unity. The ecology of language is the interaction between an existing language and its environment (people and communities that use that language or sociolinguistics). So that ecological parameters such as connectivity, environmental environment and diversity. Ecolinguistic studies are used because the ecological concepts in the language of the Angkola customs can be revealed collectively in the traditional ceremonies in Angkola. Ecology was first introduced by Ernst Haeckel (1834-1914).

Ecology comes from the Greek oikos which means house, man's immediate suroundings. Ricklefs (1976: 1) defines ecology as follows. Ecology is the study of plants and animations, as individuals and together in populations and biological communities, in relation to their environments - the physical, chemical, and biological characteristics of their surroundings. That was confirmed by Haugen in Peter, (1996: 57) Language ecology may be defined as the study of interactions between any given language and its environment.

Ecology is a branch of science that studies how living things can sustain their lives by establishing relationships between living things and with inanimate objects in their place of life or environment.

Ecolinguistics, interdisciplinary science, is an umbrella for all research on language (and languages) that is linked in such a way to ecology as Crystal (2008: 161-162) puts it in A Dictionary of Linguistics and Phonetics 6th Edition, explain that, ecolinguistics (n.) In linguistics, an emphasis-reflecting the notion of ecology in biological studies-in which the interaction between language and the cultural environment is seen as central; also called the ecology of language, ecological linguistics, and sometimes green linguistics. An ecolinguistic 
approach highlights the value of linguistic diversity in the world, the importance of individual and community linguistic rights, and the role of language attitudes, language awareness, language variety, and language change in promoting a culture of communicative peace.

The ecology of language, ecolinguistics or green linguistics as objects of ecolinguistic studies aims to increase ecological awareness with language and ecological symptoms from various perspectives. Views on the environment and the relationship between the charm of language as part of ecology. The conception / view of language and linguistics also shows that language and the environment are considered as potential study objectives. Ecolinguistic studies linking the biological, sociological, and ideological dimensions in the language of the relationship between the three models can be described according to Ricklefs (1976: 1) Mühlhäusler Peter, (1996: 57) Crystal (2008: 161-162) Dialoque Model in Jeppe Bundsgaard $\&$ Sune Steffensen (2000: 10)

According Avonina in Yusni (2018) local wisdom that everything associated with traditional forms as a by certain cultures. Local wisdom gained in interacting with indigenous communities thus create peace sense of ease in the interaction with the interaction obtained good values, so as to create decent personality as a mirror traditional values regularly

Angkola customary traditions are still often held, despite changes and adjusting customs in the times, so that traditions begin to be simplified according to needs. Angkola traditional ceremonies are believed in sirion ceremonies such as: 1) hasosorang ni daganak (children born), 2) haroan boru or as a patobang child or mangupa, and (3) marmasuk bagas na imbaru (entering a new home, (Harahap, 1993: 116)

Roland Barthes (1957: 140-142) there are three characteristics of values, namely: 1) values related to the subject; 2) values appear in a practical context, where subjects want to make something; 3) value concerns the properties that are 'added' by the subject to the properties owned by the object, the value not possessed by the object in itself. Wisdom will produce noble values and norms for the benefit of living together.

At the application stage, wisdom will direct the application of these values and norms in the form of behavior correctly, not to distort or distort the values or norms for individual interests.

\section{Research Method}

Qualitative methodology is a research procedure with results in the form of descriptive data that can be linked through the subject itself. Descriptive qualitative research methodology using primary data sources is Angkola traditional ceremony data and secondary data in the form of reference books, journals and some previous research, data analysis by interpreting Schaltzman and Strauss data (1973: 110-111) interpreting descriptive, descriptive analytic or theoretical data substantive, including collected text data, presentation of data, and drawing conclusions or verification based on Ecolinguistics studies and studies of Barthes values. This research was conducted with a qualitative descriptive approach. Moleong (2010: 5) states that qualitative research is research that produces analytical procedures that do not use statistical analysis procedures or other means of quantification. Denzin and Lincoln in Moleong (2010: 5) state that qualitative research is research that uses a natural setting, with the intention of interpreting phenomena that occur and are carried out by involving various existing methods. Qualitative research methods are often called naturalistic research methods because their research is conducted in natural conditions; also called the ethnographic method, because initially this method was more widely used for research in the field of cultural anthropology; referred to as a qualitative method, because the data collected and analysis are more qualitative (Sugiyono, 2013: 8). From the opinions of some of these experts 
it can be concluded that the data in qualitative research is to describe, review, and describe the data.

Qualitative research is also subjective or in the view of researchers and the truth can be reconsidered by other readers. This is of course different from quantitative research that is objective in nature. The truth of the data is absolute. Researchers who interpret the text, then he must permeate the contents of the text. The intelligence and accuracy of the interpreter in interpreting the meaning will determine the success or failure of studying the traditional text. Qualitative research methods are carried out by describing data, analyzing the value of local wisdom in the Angkola traditional text.

\section{Discussion}

The agrarian Angkola community certainly has a shared relationship with plants, forests, and the universe. Localpeoples of plants are smballs which are believed to have meanings that represent the characteristics of these plants. Thus, forests, the natural environment remain alive and secure as macrocosmic and microcosmic relations between the universe and humans and living things. Damage to the environment then the Angkola localpeople can no longer because every traditional ceremony is always represented by nature through plants that are accompanied by the traditional ceremony, so if there are no more plants then the traditional ceremony will end too.

\subsection{Character Recognition of Plant Names}

\section{a. Introduction to Plants at the Entrance Gate of the Traditional Ceremony}

The introduction of plants to all people in Angkola has begun from childhood, this is by introducing some plants that are used at the entrance gate at the place of traditional ceremonies. Sugar cane, coconut, long stems, aru aya (banyan) leaves, jali-jali flowers, bamboo stems, and coconut leaves.

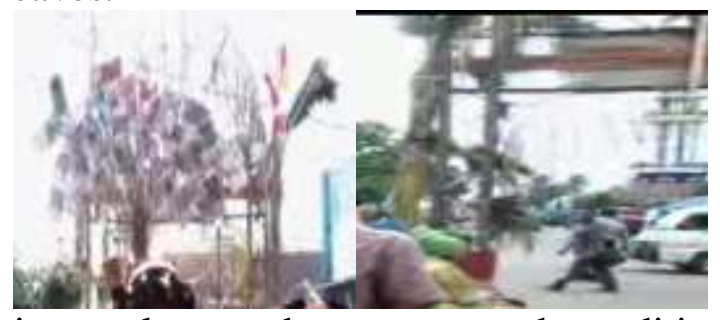

Figure 1. Introduction to plants at the entrance to the traditional ceremony (D2. UAA.MHG)

\section{b. Introduction of Plants at the Mangupa Traditional Ceremony}

The use of plant lexicons in Angkola traditional ceremonies is 23 lexicons, such as: Andor, ayu ara, banirna, Batangna, burangir, bulung, bulungna, bulung ni torop, dapdap, soda, gambir, jagar-jagar, karambir, laklak, lapok, lapung, maranggas, napuran, pining, sisuanon. suan-suanan, tobu, torjangna, torop. (D1. UAA.TRB)

The use of plants used in the Angkola custom mangupa ceremony as many as 10 lexicons such as Bulung ujung, Burangir 'sampe-sampe, Indahan, Ulos' traditional cloth, Anduri, Gambir, Imbako, Soda, Amak lappisan, timbako, pining. 
Table 1. Herbs Used at the Mangupa Ceremony

\begin{tabular}{|l|l|l|}
\hline No. & \multicolumn{1}{|c|}{ Plant Names } & \multicolumn{1}{c|}{ mean } \\
\hline 1 & Bulung ujung & Banana leaf \\
\hline 2. & Burangir 'sampe-sampe & Betel leaf \\
\hline 3. & Indahan & White rice \\
\hline 4. & Ulos 'kain adat & Cotton \\
\hline 5. & Anduri & Handsome bamboo \\
\hline 6. & Gambir & Gambir \\
\hline 7. & Imbako & Tobacco \\
\hline 8. & Soda & Lime betel \\
\hline 9 & Amak lappisan & Layered Pandan Mats \\
\hline 10 & Pining & betel nut \\
\hline
\end{tabular}

Source: (D2. UAA.MHG)

Pangupa apparatus consisting of: betel, gambier soda, areca nut, and tobacco are foods that are consumed by parents when there is a crowd or at traditional ceremonies, betel and pangupa devices are light meals such as bon-bon (confectionery). General pangupa device as a light meal that also functions as a medicine, both for medical treatment and non-medical treatment.

\section{c. Introduction of Plants at the Tapian Raya Building Ceremony}

Traditional ceremonies at the building's main building were the ceremony of the bride and groom, in the ceremony the plants were used. The lexicon of plants in the Angkola traditional ceremony was 9 lexicon, such as: young coconut, sidingin-dingin leaves (cocor bebek), a kind of grass, rice that had been given turmeric (unique), betel (burangir), soda (whiting), pandan leaves, flowers. The use of plants is the same as for flouring. Knowledge about plants and the environment for the Angkola localpeople was introduced early on. The Angkola community has inherited traditional knowledge related to nature that has been given to the next generation.

\section{d. Plant Introduction to Traditional Ceremonies Entering New Homes}

At the ceremony of entering a new house the use of plants The use of lexicon of plants in the traditional ceremony of Angkola as many as 3 lexicon, such as: banana bark, cocor bebek leaf (sidingin-dingin leaf), aru aya leaf, leaves are placed on the floor at the entrance will be stepped on by the bride on her return from the Ceremony of Tapian Raya Gedung.

The introduction of plants used by his ancestors verbally and the practice has always been done from generation to generation for his children and grandchildren. So that there has been a direct interaction with the natural environment, thus forming knowledge about love with plants and the natural environment. This is supported by livelihoods from agriculture so that the people of Angkola are close to nature. So that knowledge about plants and nature is quite close. So, from childhood for the people of Angkola, a love for plants and nature has been embedded.

\subsection{The Use of Lexicon of Plants in Local Texts}

\section{a. Burangir (Sirih Leaf) as the Opening Ceremony of the Angkola custom}

Betel leaf 'burangir' (Piper Betle) as a lexicon of plants used in the opening ceremony of the Angkola custom ceremony, Sirih as a snack such as sweets (bon-bon) when consumed will emit red water which becomes a symbol of blood as a brotherhood. Adhesives between localcommunities and the symbol of dalian na tolu. Philosophical red betel when eaten 
means suhut and kahanggi blood relations as a sign of brotherhood and symbol of unity. See the text of a traditional ceremony that reveals betel below:

"Mula hata ni burangir, burangir na hombang na be artina dipabaris sanga pe dipabajon, ma takkas on artina muda dibarita on tiada lain artina maroban sijob niroha." (D3. UAA.MGLG)

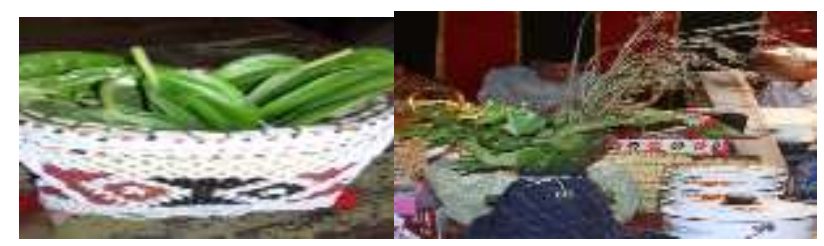

Figure 2. Burangir (betel leaf) and Jagar-jagar

"Waktu manyurduon ima, burangir taon-taon, badan disi tarsigop mada on da nazar nami, ima kira-kira 23 tahun na lewat.” (D2. UAA.MHG)

Betel function and the device as a burangir sampe-sampe (betel) which aims to convey everything that is stored in the heart. Betel also as a sign of a traditional ceremony has been opened. In addition, betel is used to invite and betel as well as being eaten when resting in the tradition of Angkola.

"Jadi dison surdu burangir munu, Surdu artina dohot burangir munu na tarpayak di pattar bolak.” (D1. UAA. TRB)

Betel as a symbol usually used to invite and open Angkola traditional ceremonies, as well as betel with a set (tobacco, areca nut, gambier and soda) is a sign of opening the Angkola custom. The betel function for the Angkola community is used in various opening ceremonies and traditional traditions (marriage ceremonies, mangupa, and other traditional ceremonies).

Philosophical burangir (betel leaf) as a sign of the relationship between localpeoples custom dalihan na tolu the environment as a producer of flora used in traditional ceremonies. Thus, it can be stated that the concept and understanding of the environment with environmental awareness, wisdom, and care become an integral part of the public trust in Angkola. Awareness, wisdom, and concern for the environment, however, environmental destruction will also damage the customary structure of Angkola.

Implicitly the objects used as material in the mangupa traditional ceremony show the relationship and appreciation of human relations with the natural surroundings. Thus, the symbolic meaning of pangupa material shows appreciation for nature that between humans and nature around it as an inseparable relationship, because it has a mutual relationship between nature and humans

\section{b. Value of Character Wisdom like Siala Sampagul}

The character value of advice to live like a banana tree by using figurative sentences at the mangupa ceremony so that life can be harmonious and peaceful is conveyed in a figurative sentence. The values of local wisdom conveyed so that they can live peacefully in a household using figurative language such as:

syukur ma nian seia sekata songon siala sampagul nina, rap tu jae rap tu julu..." yang meaning: syukurlah seiya sekata seperti siala (D2. UAA.MHG)

The advice given by using the figure of Siala Sampagul is a fruit that tastes sour in the form of a bunch that is quite sturdy because it is united. 


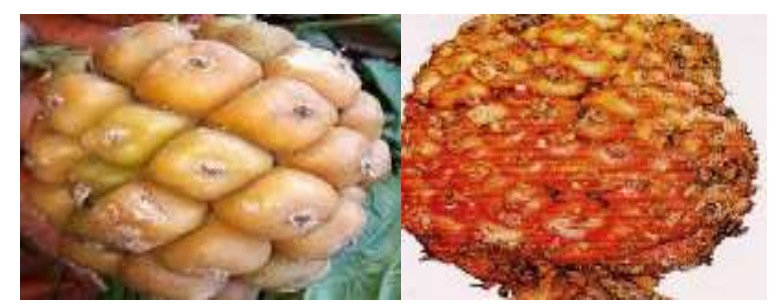

Figure 3. Siala Fruit Phaemoeria speciosa or Elletaria speciose (Basyral Hamidi Siala Sampagul)

Text showing local characters using plant names in the text: Songon siala na sampagul, rap tu ginjang rap tu toru. sampagul said always together here and there. (D2. UAA.MHG)

The chalice used to compile is used in traditional texts which show the cohesiveness between dalihan na tolu and suhut sihabolonan in cooperating with one step in tune. Which shows compactness. Characteristics of loving the environment as a symbol of plants that show the closeness of localpeoples with the environment.

\section{c. Character Wisdom Value like Banana Trees}

The value of local wisdom in the sentence of advice delivered by the grandmother (woman), “...a) happisang ulang dua kali mardakka ... ta pa bahat doa songoni na hudokkanon Pahompu on, ... b) sakali sampur happisang ulang dua kali mardakka on marduppang aso tarsambung tu jae dohot tu julu..." Which means: ... a) bananas do not bear fruit twice ... b) sakali bananas do not bear fruit twice, smart family members here and there.

The local wisdom value of the advice sentence meant by "happisang repeat twice mardakka" is reinforced by the second sentence of advice. "Sakali sampali rejoices twice mardakka on marduppang aso tarsambung tu jae dohot tu julu" (D2. UAA.MHG) meaning of the value of local wisdom advice that if it can be the same as a banana tree to bear fruit only once the age of the banana tree, tamsilan grandmother (pr) also used for marriage, preferably once in a lifetime, not twice, doubling twice. So the advice on married life is to hope that the family becomes a peaceful and prosperous family or Arabic is known as sakinah mawaddah warohmah family. This was also confirmed by cleverly connecting friendship relations with relatives who were emphasized with sentences: tarsambung tu jae dohot tu julu, which means smart family life to the family of male and female family.

Bulung ujung (banana leaf) the tip used in the mangupa tradition functions to base and cover the pangupa material. Bulung ujung, has a sturdy nature as a marker called a protector that is able to provide coolness as a sign of traditional symbols. The philosophical meaning of banana leaf is a protector and a custom sign protecting a custom symbol of the greatness of the adat.

\section{d. Character Wisdom Values Like Indahan (white rice)}

Indahan (white rice) as a staple food has a high meaning of the parents' high affection for their children and son-in-law. White rice symbolizes purity, cleanliness, truth, sincerity, sincerity, and unity. Rice consists of many items (not just one item) has a sticky nature and can be integrated, so that it means unity in a large family of daliahan na tolu, with the understanding that all family members can be united despite having differences. The goal is that the bride can blend in with all big families, have a sincere (sincere), true, and clean soul.

\section{e. Character Wisdom Values Like Ulos (cotton)}

Ulos (traditional cloth made from cotton) abit Batak, Abit Godang woven AngkolaSipirok). Traditional cloth has a high traditional meaning because it is used every traditional 
ceremony. Ulos Godang which symbolizes the protector, with the cover of the cloth, it means that there is protection for the souls who are rejoicing. Ulos Godang serves to honor the guest of honor used at traditional ceremonies, customary symbols when ulos given by parents to their daughters at a marriage ceremony, Ulos has philosophical significance as a sign of customary giving of mora to boru children.

Wisdom of character and environmental care are integral to the public trust in Angkola. As wisdom, care for the environment by maintaining the relationship between localpeoples and the beautiful environment

\section{f. Wisdom Value of Character Sontang (Gambir)}

The leaves of gambir (sontang) white creepers when dry with a sense of sepat or kelat, gambir leaves symbolize anak boru. This symbol signifies the position of anak boru in the custom dalihan na tolu, which is a sweet and sweet life. The symbol in the traditional language of Angkola is called: "Anak boru na mamboto sapot dohot tonggi ni na Marmora" Gambir leaves as a complement to betel eating philosophical meaning of traditional anak boru signify brotherhood and symbol of unity.

\section{g. Value of Wisdom Character Like Anduri (Tampi)}

Anduri as a tool for winnowing rice by being faned up and down, which symbolizes calling tondi (soul) back to the body and aims to distinguish good and bad. Upward movements signify good things, must be followed. Downward movements indicate bad things, you should leave.

Every corner of the Anduri edge is tied to the rattan, the function of concluding, bending, and weaving and other functions. That implies the meaning of flexible and flexible paradaton regulations, so that customs and paradaton are quite flexible in dealing with various problems by way of consensus by using the adat order of dalihan na tolu. Anduri (tampi) rectangular woven bamboo is philosophically meaningful togetherness and mutual cooperation (please help woven symbol).

\section{h. Hordang (Tugal' 'wood) Tools for planting)}

On Angkola's customary advice from the edge of the building highway: (indeed the bridegroom and bride with yellow rice) then in the text:

"Didokkon anak baen dua, antong $u$ hordang mada, U hordang (tugal 'wood', a funnel tool to plant corn seeds in the ground) di ginjang rambut, di son otak dohot pikir, Maro dongan si sada, dua tolu, antong denggan ma ho tu kahanggimu, elek ma ho, maranak boru, sombah ma ho tu moramu. Sada, dua tolu, opat, lima, onom, pitu, pitu cundut sai so soada mara horaskon (berseru) horas, horas, horas. (D1. UAA.TRB)

“...yang menjadi lahanan ni baga-baga baen adong do na manjadi suan-suanan ni omputta na parjolo. Sundut burangir na haraduon di surduon tondi dohot bandanna botima.

Localpeoples' environmental knowledge is inherent in the Angkola custom. By including flora, plants in the environment and how to appreciate plants by accompanying them as traditional instruments, as well as interpreting traditional symbols that have plant character values as Angkola's cultural characteristics. Thus, the Angkola localpeople often use plants and their links with high respect for the environment that is continuously instilled by traditional leaders in each generation to the next generation so that it remains imprinted until now. 


\subsection{Educational Characteristics of Plant Lexus Meanings in Customs}

Characteristic education through the plant lexicon used in adat delivered by Raja Pamusuk in Angkola adat. Customary texts are conveyed through the advice of traditional leaders such as when customary bridegroom through customary texts as knowledge through philosophical meaning of plants. Characteristics of Meanings Plants used in traditional ceremonies use symbols (see table 2 below) such as: 1) Bulung ujung (banana leaf) means to protect, nurture and withstand something, 2) burangir (Betel) Symbolizing humility, clever self-inclusion, and able to lean and not damage the leaning place (according to the betel way of life) 3) Indahan (white rice) sincerity, sincerity, and unity. Rice has the property of being easily sticky and can be fused, 4). Cotton Ulos, respect and protector, symbols of harajaon and simora-mora. 5) Anduri (Tampi) a family relationship and dalihan na tolu, togetherness, and mutual cooperation symbolized by woven). 6) Gambir symbolizes, tenacity and perseverance, 7) Timbako (tobacco) symbolizes the resistance to all trials, 8) Soda (Cretaceous) symbolizes a clean heart of pure intentions, soft but lime can also be hard, and hurt, 9) symbolizes the nature of nature hard and high degree, honest and open.

Table 2. Characteristics of Angkola Local Wisdom through the Meanings of Plants

\begin{tabular}{|c|l|l|}
\hline No. & Plant Names & \multicolumn{1}{|c|}{ Mean Symbol } \\
\hline 1 & Bulung ujung & $\begin{array}{l}\text { protect, protect, and hold against } \\
\text { something }\end{array}$ \\
\hline 2. & Burangir & $\begin{array}{l}\text { Be humble, adaptive, and able to lean and } \\
\text { not damage the leaning place }\end{array}$ \\
\hline 3. & $\begin{array}{l}\text { Indahan } \\
\text { 'Nasi putih' }\end{array}$ & $\begin{array}{l}\text { has a sticky nature and can be united in } \\
\text { sincerity, sincerity, and unity }\end{array}$ \\
\hline 4. & Ulos 'kain adat & $\begin{array}{l}\text { respect and protector, symbols of } \\
\text { harajaon and simora-mora }\end{array}$ \\
\hline 5. & Anduri & $\begin{array}{l}\text { family relations and dadap na tolu, } \\
\text { togetherness, and mutual cooperation } \\
\text { symbolized by plait }\end{array}$ \\
\hline 6. & Gambir & tenacity and perseverance \\
\hline 7. & Imbako & Tobacco \\
\hline 8. & Soda & $\begin{array}{l}\text { symbolizing a clean heart that is pure, } \\
\text { soft, but chalky, and can be hard, and } \\
\text { hurt }\end{array}$ \\
\hline 9 & Pining & $\begin{array}{l}\text { hardiness and high degree, honest and } \\
\text { open }\end{array}$ \\
\hline
\end{tabular}

Source: (D2. UAA.MHG)

Based on this, if it is associated with characteristic education through the plant lexicon used in adat with the environment in general. The Angkola community has instilled characteristics to love the environment through the lexicon of plants used in traditional ceremonies. The Angkola community has given the meaning of plants as localfoilosophysics through the nature of the plant lexicon, so that the lives of localpeople while protecting the environment, by making plants as Angkola's custom symbols in instilling the characteristics of loving the natural environment and plants. Thus, the Angkola localpeople protect the environment so that human relationships with nature are in harmony 


\section{Conclusion}

Angkola's localwisdom in its efforts to love the environment is related to the wisdom values of the culture character of the Angkola localpeople to instill a love of plants by including a plant lexicon in each traditional ceremony. Likewise also by taking the meaning and nature of the plant as a philosophical customary symbol which is used as a social behavior. can not be separated from the aspects of wisdom Angkola.

Early recognition of plants to the Angkola community by introducing plants to a) the entrance gate of the traditional ceremony, b) the introduction of plants to the traditional Mangupa ceremony, c) the introduction of plants to tapian raya bangunan, but building, d) The introduction of plants to the Customary barbokkot bagas naimbaru (Entering a New Home). It was used as a basis for planting norms or values.

The use of lexicon of plants in localtext, betel character value, character wisdom value such as Sampagul Cup, Banana Tree, Indahan (white rice), Ulos (cotton), Sontang (Gambir), Gambier leaf, Hordang (Tugal 'wood) Tools for plant.

The wisdom of Angkola Localpeople in the effort to love the environment is the education of cultural characteristics through the plant lexicon used in adat delivered by Raja Pamusuk, Raja panususnan bulung, Angkola's traditional figure at the Angkola traditional ceremony. Customary texts are conveyed through advice when it is customary to the bride as knowledge through philosophical meaning of plants. Characteristics of Plant Meanings used at traditional ceremonies use plant symbols such as: Bulung ujung (Banana leaf), burangir (Sirih), Indahan (White rice), Ulos' traditional cloth, Anduri, Gambir, Imbako, Soda, and Pining.

The Angkola tradition still functions as the glue of brotherhood among the localpeoples, as an effort to empower and strengthen the existence of the Angkola custom in order to maintain its beauty. Planting and understanding of Angkola's love for the environment and for the vegetation is driven by the customary wisdom that is carried on periodically. Essentially, the preservation of nature in Angkola is reflected in the ecological relations that are engraved through traditional traditions that use plants as Angkola's localwisdom in loving the environment and while maintaining the balance of relations between localpeoples and the environment.

\section{References}

Adisaputra, Abdurahman. (2010). Ancaman Terhadap Kebertahanan Bahasa Melayu langkat. (disertasi). PPS Universitas Udayana., Denpasar.

Adler, Patricia A. dan Peter Adler. (1994). "Observational Technique". Handbook of Qualitative Research. Norman K. Denzin dan Yvonna S. Lincoln. London: Sage Publication

Barthes, Roland. (1957). Mythologies. Paris: Editions du Seuil.

Bundsgaard Jeppe \& Sune Steffensen.2000.'The Dialectics of ecological Morphology -or the Morphology of Dialectics" in Dialectical Ecolinguistics: Three Essays For The Symposium 30 Years of Language and Ecology in Graz Desember 2000. Anna Vibeke Lind $\varnothing$ \& Jeppe Bundsgaard (eds.).

Crystal, David. (2008). A Dictionary of Linguistics and Phonetics 6th Edition. United Kingdom: Blackwell Publishing.

Mark EverardPaul JohnstonDavid SantilloChad StaddonUNEP, 2020Wood et al. (2012). Jones et al.,2008 Everard, Mark, Paul Johnston, David Santillo, Chad Staddon "The role of ecosystems in mitigation and management of Covid-19 and other zoonoses" 
Environmental Science and Policy Chad Staddon UNEP, 2020 Wood et al., 2012 Jones et al., 2008 Pages 7-17

https://reader.elsevier.com/reader/sd/pii/s1462901120306122?token=1af797a36a3dfda1 e40a0318741188f90c5d9e5815660991635121c3b8c00ff88bb8731e55415a05d1aa4556 4fa5ece1 diakses 29/6/20

Halliday, M.A.K. (1978). Language As A Social Semiotics. London : Edward Arnold Harahap, Basyral Hamidy. (2004). Siala Sampagul. Bandung: Pustaka.(ISBN 979-98049-14). Lindo, Anna Vibeke and Jeppe Bundsgaard (eds). (2000). Dialectical Ecolinguistics Three Essays for the Symposium 30 Years of Language and Ecology in Graz December 2000. Austria: Univerisity of Odense Research Group for Ecology, Language and Ecology.

Mühlhäusler, Peter. (1996). Linguistic Ecology Language Ecology and Linguistic Impealism in the Pacific Region. London: Routledge.

Moleong, Lexy J. (2010). Metodologi Penelitian Kualitatif Edisi Revisi. Bandung: Remaja Rosda Karya.

Parsadaan Marga Harahap. (1993). Horja: Adat Istiadat Dalihan Natolu, Jakarta: Parsadaan Marga Harahap Dohot Anak Boruna

Ricklefs, Robert E. (1976). The Economy of Nature A Textbook in Basic Ecology. New York: Chiron Press Incorporated.

Sinar, Tengku Silvana. (2010). "Ungkapan Verbal Etnis Melayu dalam Pemeliharaan Lingkungan." Disampaikan dalam Seminar Internasional Seminar Language, Literature, And Culture in Southheast Asia. Diselenggarakan oleh Prodi Linguistik USU dan Phuket Rajabhat University Thailand, Thailand 3-5 Juni 2010.

Sugiyono. (2013). Metode Penelitian Pendidikan : Pendekatan Kuantitatif, Kualitatif dan R\&D.

Schaltzman \& Anselm L. Strauss. (1973). Field Research: Strategies for a Natural Sociology, New Jersey: Frentice-Hall, Inc.

Watts, Richard J., Sachiko Ide, dan Konrad Ehlich. (2005). "Introduction" Politeness in Language. Richard Watts, Sachiko Ide, Konrad Ehlich (ed). New York: Mouton de Gruyter.

Yusni, K. (2018). Mangupa; An Oral Tradition of Angkola Community. Budapest International Research and Critics Institute-Journal (BIRCI-Journal). P. 51-61 